\title{
"Alles draait om de chemie"
}

Citation for published version (APA):

Bekers, O. (2015). "Alles draait om de chemie". Maastricht University. https://doi.org/10.26481/spe.20150522ob

Document status and date:

Published: 22/05/2015

DOI:

10.26481/spe.20150522ob

Document Version:

Publisher's PDF, also known as Version of record

\section{Please check the document version of this publication:}

- A submitted manuscript is the version of the article upon submission and before peer-review. There can be important differences between the submitted version and the official published version of record.

People interested in the research are advised to contact the author for the final version of the publication, or visit the DOI to the publisher's website.

- The final author version and the galley proof are versions of the publication after peer review.

- The final published version features the final layout of the paper including the volume, issue and page numbers.

Link to publication

\footnotetext{
General rights rights.

- You may freely distribute the URL identifying the publication in the public portal. please follow below link for the End User Agreement:

www.umlib.nl/taverne-license

Take down policy

If you believe that this document breaches copyright please contact us at:

repository@maastrichtuniversity.nl

providing details and we will investigate your claim.
}

Copyright and moral rights for the publications made accessible in the public portal are retained by the authors and/or other copyright owners and it is a condition of accessing publications that users recognise and abide by the legal requirements associated with these

- Users may download and print one copy of any publication from the public portal for the purpose of private study or research.

- You may not further distribute the material or use it for any profit-making activity or commercial gain

If the publication is distributed under the terms of Article $25 \mathrm{fa}$ of the Dutch Copyright Act, indicated by the "Taverne" license above, 
Prof. dr. Otto Bekers

Faculty of Health, Medicine and Life Sciences

\section{"Alles draait om de chemie"}




\title{
"Alles draait om de chemie"
}

\author{
Rede
}

uitgesproken bij de aanvaarding van het ambt bijzonder hoogleraar Klinische Chemie aan de Universiteit Maastricht in de Faculty of Health, Medicine and Life Sciences op 22 mei 2015 door

Otto Bekers 
Mijnheer de rector,

Leden van de Raad van bestuur,

Leden van het College van Toezicht,

Gewaardeerde collega's en vakgenoten,

Lieve familie en vrienden,

Eén hele goedemiddag, ook ik heet jullie van harte welkom in de mooiste stad van Nederland alwaar, op het rechter plaatje, dit prachtige ziekenhuis staat.

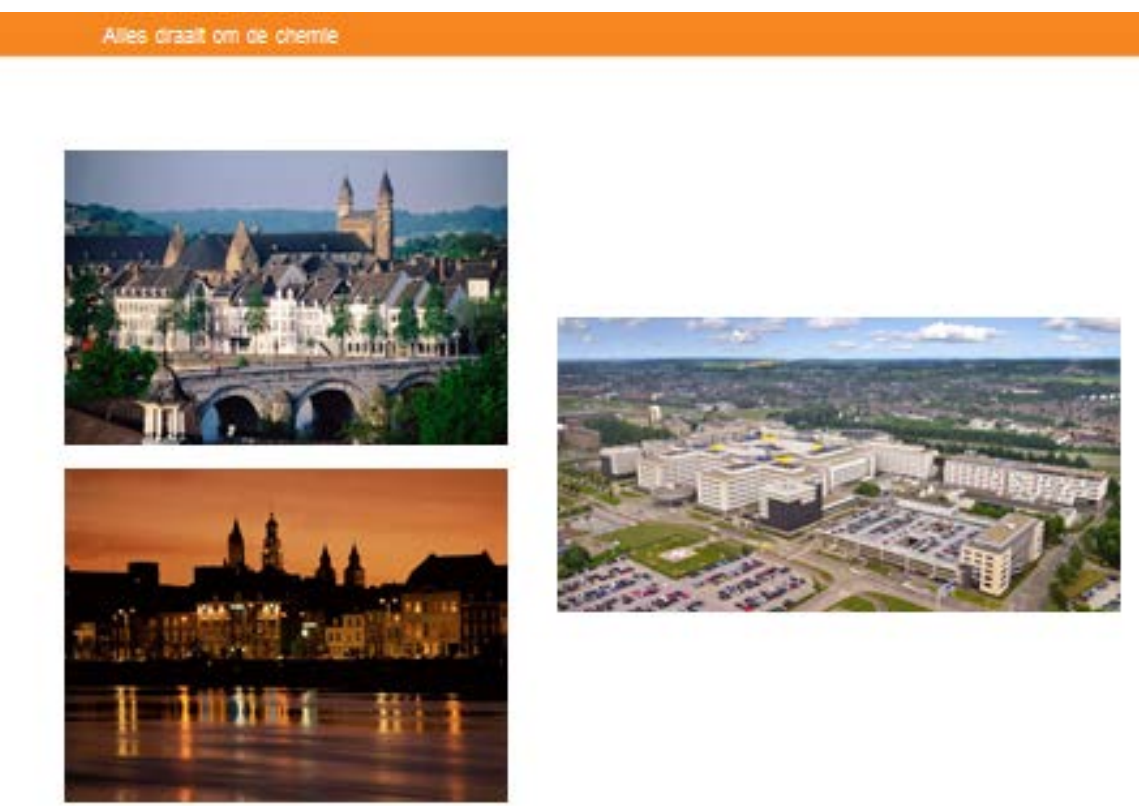

Maastricht UMC.

Ik ben verheugd en dankbaar dat $u$ hier in grote getale naar toe bent gekomen om te luisteren naar mijn inaugurele rede voor het aanvaarden van de bijzondere leerstoel Klinische chemie. Sommige van u komen van dichtbij, maar er zijn er ook velen die van ver zijn gekomen zoals uit het westen van het land, Groningen en zelfs uit Rome.

De Universiteit Maastricht is in de wereld bekend om zijn manier van onderwijs geven, getypeerd als probleem gestuurd. In het probleem gestuurd onderwijs oftewel PGO staat de student centraal. PGO houdt in dat de student kennis opdoet door samen te werken met andere aan concrete problemen. Dit wordt besproken in onderwijsgroepen en er wordt vervolgens op zoek gegaan naar antwoorden en oplossingen. Tijdens het schrijven van mijn rede werd ik ook met een probleem geconfronteerd en om die reden heb ik 2 redes geschreven. Eén puur 
wetenschappelijke en een meer populairdere versie. Normaliter moeten de studenten in Maastricht de problemen tackelen, maar hier wil ik aan u vragen dit probleem voor mij op te lossen. En ik laat aan u de keuze welke rede ik ga uitspreken. We gaan niet polderen, de meerderheid beslist. Indien uw voorkeur uitgaat naar de ingewikkelde puur wetenschappelijke voordracht dan mag u uw hand opsteken, als u liever de meer algemene voordracht verkiest dan doet u even niets.

Ja, het mogelijk duidelijk zijn wat de meerderheid is en daarom zal ik de meer algemeen toegankelijkere niet puur wetenschappelijke rede voor $u$ brengen. Wel laat ik $u$, en dan met name voor de insiders, hier nog even zien wat $u$ onder andere gaat missen.

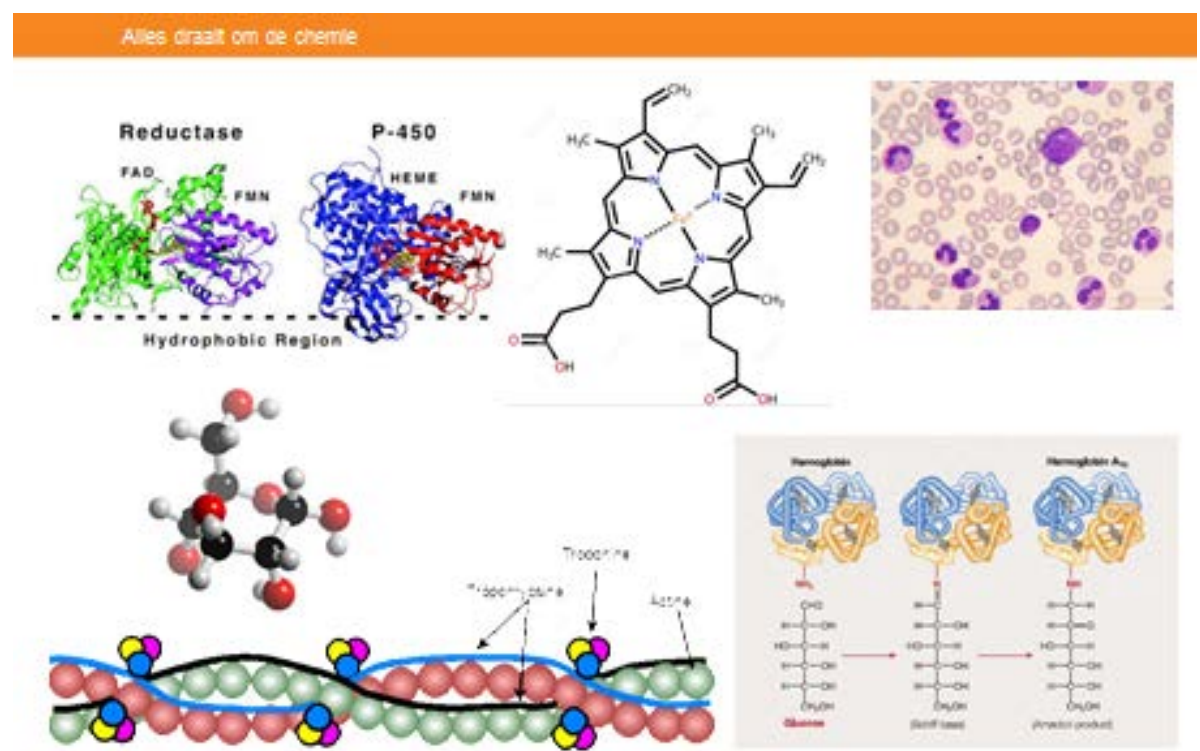

Masstricht UmCe.

En ik begin dan nu, ja - u heeft er zelf voor gekozen, met iets niet wetenschappelijks .

$U$ denkt misschien dit is geen helemaal geen chemie, dat klopt dit is biologie. In dit filmpje komen veel zaken naar voren, die ik zeer herkenbaar vind. De leeuwen in het filmpje hebben geluk en ik ben zelf een leeuw en kan mij goed met hun identificeren, tevens is het verrassend, snel en humoristisch en dat laatste is in dit leven van groot en soms onderschat belang. Maar daarnaast is er zoals altijd ook een keerzijde - je zou de springbok maar zijn. 
Als je biologie en chemie samen neemt kom je bij de biochemie en het stapje naar de klinische chemie is dan snel gemaakt.

Waar ik u vanmiddag in wil mee nemen is een indruk geven wat de klinische chemie inhoudt, hoe je een specialist klinische chemie en laboratoriumgeneeskunde wordt en wat voor werkzaamheden je vervolgens verricht. Om het één en ander meer tot de verbeelding te laten spreken wil ik een aantal voorbeelden uit de klinische praktijk aan u voorleggen. Vervolgens geef ik u een impressie waar wij ons op dit moment in Maastricht mee bezig houden en hebben gehouden en tot slot zal ik kort stilstaan bij toekomstige ontwikkelingen.

- Klinische Chemie

- Voorbeelden

- Hartinfarct

- Farmacogenetica

- Diabetes Mellitus

- POCT

- Klinische chemie in het MUMC

- Toekomst perspectief

Masstricht UMC.

\section{Maar om te beginnen wat is klinische chemie?}

De klinische chemie is het vakgebied dat zich bezig houdt met medisch laboratoriumonderzoek in lichaamsvloeistoffen

Deze lichaamsvloeistoffen kunnen zeer divers zijn - ontlasting, speeksel, hersen-, buik of knievocht maar urine en met name bloed zijn de meest voorkomende materiaalsoorten. Bij circa $75 \%$ van de patiënten die zich in een ziekenhuis melden wordt er bloed afgenomen en laboratoriumonderzoek verricht. Vele van u kennen wellicht een laboratoriumformulier waarop een arts kan aankruisen welke onderzoeken hij of zij nuttig acht. Dit is dan met name om een ziekte aan te tonen dan wel uit te sluiten of het verloop van een ingezette behandeling te volgen. Tevens kunnen analyses worden verricht ter 
preventie van ziekte of om een prognose te kunnen geven. Tests waaraan u kunt denken betreffen onder andere: nieraandoeningen, hartafwijkingen, long-, maag-, lever- of darmaandoeningen, endocrinologische problematiek, dit zijn zaken betreffende de hormoonhuishouding, allergieën, tumormerkstoffen, de aanmaak, verdeling en afbraak van cellen in het bloed of te wel de hematologie waaronder ook de bloedstolling valt en immunologische tests, die afweerreacties op lichaamseigen en lichaamsvreemde stoffen bestudeerd. Ook verzorgen de klinisch chemische laboratoria over het algemeen de uitgifte van bloedproducten. Dus als er na bijvoorbeeld een ernstig trauma of operatie bloed aan een patiënt gegeven moet worden zorgt het laboratorium ervoor dat de patiënt het juist uitgetypeerde bloed krijgt toegediend.

Om u een beeld te geven neemt de Centrale Bloedafname van het Maastrichts Universitair Medisch Centrum plus, welke onderdeel is van ons laboratorium, per jaar bij ruim 230.000 patiënten bloed af en verricht het Centraal Diagnostisch Laboratorium ruim 3,3 miljoen analyses per jaar.

\section{De opleiding tot laboratoriumspecialist klinische chemie}

Recent is de opleiding tot klinisch chemicus vernieuwd en is laboratoriumspecialist klinische chemie de juiste term. Deze laatste term is nog niet geheel ingeburgerd en frequent wordt nog de naam klinisch chemicus gebezigd, ik zal dit in deze rede ook zo af en toe doen, ik begeef dan dus even op glad ijs. In Nederland zijn er 309 registerleden en er zijn momenteel 61 mensen in opleiding. Toen Marja van DieijenVisser in 1993 aan deze universiteit haar rede uitsprak waren er op het totaal van 286 registerleden 11 vrouwen en onder de assistenten in opleiding waren dat er 3 van de 22; in totaal $4,2 \%$. Ik was in die tijd net met mijn opleiding gestart en weet nog goed dat we de dames erg miste. Momenteel zijn er van de 309 registerleden 196 man en 113 vrouw en 44 van de 61 opleidelingen zijn dames; dat is in totaal momenteel 42,5\%. De heren zijn dus nog steeds in de meerderheid, maar ik verwacht dat dit niet meer voor heel lang zal zijn. De opleiding tot laboratoriumspecialist klinische chemie is een vierjarige postacademische opleiding en om in aanmerking te komen voor een opleidingsplaats dient een kandidaat te beschikken over een afgeronde universitaire master in geneeskunde, farmacie, biochemie, medische biologie of een vergelijkbare opleiding en een promotie strekt tot aanbeveling. Zoals al eerder aangegeven is het curriculum een aantal jaren geleden aangepast en is er meer aansluiting gezocht bij de medische opleidingen. Deze aansluiting is er niet alleen bij de opleiding 
gekomen maar vanaf 1 januari jongstleden zijn de klinisch chemici toegetreden tot de Federatie Medische Specialisten en dit is voor onze beroepsvereniging een mijlpaal. $\mathrm{Na}$ de basisopleiding is er tevens de mogelijkheid je te specialiseren, momenteel zijn er 12 specialisten met de aantekening erfelijke metabole ziekten, 20 met hematologie en 19 voor de endocrinologie.

\section{Dan ben je geregistreerd}

En ga je binnen een klinisch chemisch laboratorium werken. Ik wil nog even vermelden dat waar ik in deze rede spreek over laboratorium ik het Centraal Diagnostisch Laboratorium bedoel. Vanzelfsprekend wil ik hierbij de overige laboratoria van ons ziekenhuis te weten de Klinische Farmacie, Klinische Genetica, Medische Microbiologie, Transplantatie Immunologie en Pathologie hiermee niets te kort doen. Maar de komende 35 minuten is het CDL even het laboratorium.

Zelf heb ik daar lang uitgekeken naar een baan als klinisch chemicus, dat dit in Maastricht zou zijn had ik niet 1,2,3 verwacht. Als intermezzo wil ik u even meenemen naar mijn eigen jeugd. Als 15-jarig jongetje werkte ik als vakantiekracht in de zomer van 1977 al binnen het laboratorium van het toenmalige Westeinde Ziekenhuis, waar mijn moeder analiste was. Ik werkte daar op het zo gehete bloedsuikerlab en prikte daarom ook bloedsuikers bij patiënten in het ziekenhuis. Heden ten dage met alle kwaliteitssystemen en bekwaam- en bevoegdheidscertificaten is dat ondenkbaar. Ik heb nog 5 achtereenvolgende zomers aldaar vakantiewerk gedaan en ben de klinisch chemici van toentertijd hiervoor nog steeds dankbaar want daar werd als 15 jarige mijn interesse voor het vak gewekt. En nu sta ik hier 38 jaar later te oreren, iets wat ikzelf nog steeds verrassend vind. Maar dan ben je dus geregistreerd en ga je aan het werk; binnen een laboratorium zijn er diverse werkzaamheden te onderscheiden. Het gehele proces van aanvraag tot uitslag, in Maastricht vaak afgekort tot VATU, valt onder de verantwoordelijkheid van de laboratoriumspecialist klinische chemie. In grote perifere en universitaire ziekenhuizen zijn meerdere laboratoriumspecialisten aanwezig met ieder zijn eigen aandachtsgebied. Ook alle managementtaken behoren tot de werkzaamheden. Als we het proces van VATU bezien kunnen we hierin drie fases onderscheiden de pre-analytische, de analytische en de postanalytische fase. De pre-analytische fase is alles wat er dient te gebeuren alvorens het monster geanalyseerd wordt. Wat hier onder andere aan de order komt is monster- en patiëntidentificatie, het afnemen van het bloed in de juiste buizen, het transport naar het laboratorium en het registreren en voorbewerken van het 
monstermateriaal. Dit gehele proces wordt veelal onderschat. Er is onderzocht dat ca. $60 \%$ van de fouten in het gehele proces in de preanalytische fase plaatsvindt. Vervolgens wordt het monster geanalyseerd. De laatste decennia heeft er binnen ons vakgebied een grote automatiseringsslag plaatsgevonden. Maar gelukkig zijn er ook nog vele handmatig gespecialiseerde bepalingen over gebleven. Van groot belang is natuurlijk dat we de juiste uitslag met voldoende nauwkeurigheid rapporteren. Hiervoor wordt er heel veel aan kwaliteitscontrole gedaan. lets wat bij de laboratoriumspecialisten in de genen zit.

Als we dus na de analyse het juiste resultaat hebben verkregen wordt dit gerapporteerd aan de aanvrager zijnde een specialist, huisarts, verloskundige, verpleeghuisarts, psychiater of andere medicus. Daarnaast hebben de laboratoriumspecialisten ook een belangrijke adviserende rol. Zo kunnen wij advies geven omtrent de interpretatie van met name afwijkende uitslagen, welke bepalingen het beste verricht kunnen worden, hoe betrouwbaar de uitslagen zijn en welke vervolg testen eventueel gedaan kunnen worden.

\section{Enkele voorbeelden uit de klinische praktijk}

Om de rol van de klinische chemie duidelijk naar voren te laten komen wil ik u vier voorbeelden uit de klinische praktijk schetsen. Isaac Newton, een bekend chemicus, zei ooit: Bij het leren van de wetenschappen werken voorbeelden meer uit dan theoretische uiteenzettingen. Daarom ben ik ook blij dat $u$ voor deze rede hebt gekozen.

Het eerste voorbeeld is het acute myocard infarct in de volksmond ook wel aangeduid als hartaanval. In Nederland zijn volgens het Centraal Bureau voor de Statistiek in de periode 2009 tot en met 2012 bijna 27.000 mensen overleden aan een acuut hartinfarct. Het acuut hartinfarct is daarmee binnen de groep van hartziekten de belangrijkste doodsoorzaak. Risicofactoren voor versneld ontwikkelen van een myocard infarct zijn en ik wil natuurlijk de mannen hier aanwezig niet ongerust maken maar het mannelijk geslacht is een risicofactor en voor de oudere mannen, een hoge leeftijd is ook een risicofactor, andere factoren zijn het voorkomen van hartklachten of vaatlijden in de naaste familie, diabetes mellitus, hoge bloeddruk, hoog cholesterol, roken, alcoholmisbruik, weinig bewegen, ongezond eten, overgewicht en lichamelijke of psychische stress. Dit zijn er nogal wat en sommige factoren zijn in onze huidige maatschappij bijna niet te voorkomen. Je zou bijvoorbeeld maar een inaugurele rede moeten houden. Het MUMC plus wil mensen die een myocard infarct overleven vanzelfsprekend zo goed mogelijk helpen maar de strategische missie voor 2020 gaat veel 
verder dan dat want er wordt door ons MUMC tevens gestreefd naar gezondheidsbehoud en gezondheidsbevordering oftewel Gezond Leven.
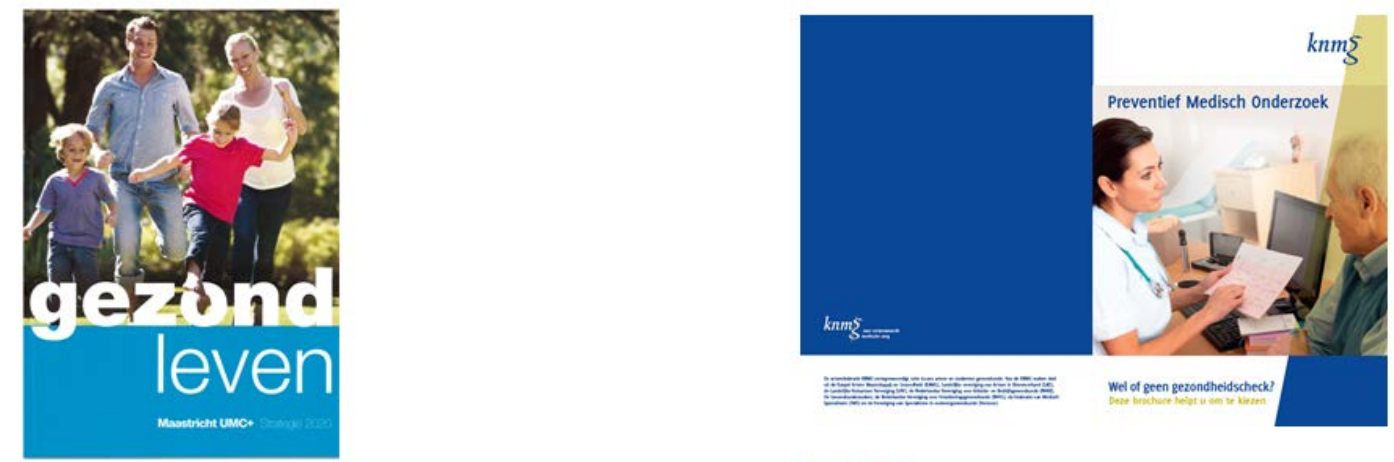

De rol van preventief testen krijgt hierin in de toekomst mogelijk een belangrijkere rol. Onze maatschappij veranderd en ik vraag me af hoelang het nog zal duren vooraleerst consumenten zelf hun eigen bloed willen laten onderzoeken. De artsenfederatie KNMG heeft hier zeer recent zelfs een advies over uitgegeven en mocht uw interesse gewekt zijn de folder hieromtrent is te vinden op de website van de KNMG.

Maar terug naar het laboratorium en de rol die het speelt bij het acute myocard infarct.

\section{Hoog-sensitieve troponine bepaling}

Diagnose acuut hartinfarct:

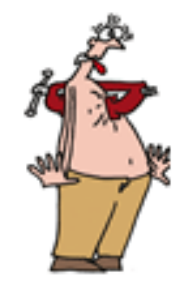

pijn-op-de-borst

zweten

discomfort

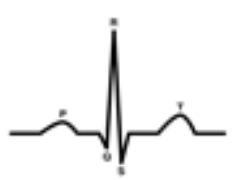

ST afwijking $O P$ ECG [5-10\% van patiënten]

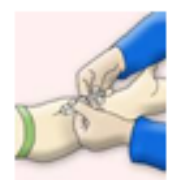

Stijging van hartmerkers

in bloed na 3-6 uren troponine $T$ of I

tijd na binnenkomst op eerste hulp 
Als een patiënt verdacht wordt van een acuut hartinfarct en binnen komt op de eerste hulp moet er snel gehandeld worden. Hoe kunnen we nu een acuut hartinfarct herkennen zodat we patiënten kunnen redden van deze levensbedreigende situatie? Patiënten komen binnen met klachten van pijn op de borst. Slechts een klein gedeelte vertoont een afwijking op het hartfilmpje ofwel het elektrocardiogram. Voor het merendeel van de patiënten zijn hartmerkers uit het bloed nodig om te bevestigen of het om het hart gaat en niet bijvoorbeeld een long- of maagaandoening. In geval van een hartinfarct zullen de hartmerkers in het bloed een stijging laten zien in de tijd. De internationale richtlijnen geven aan dat hoog sensitieve troponine bepaald moeten worden omdat deze merkers hart specifiek zijn. Naast dat deze merkers voor de diagnostiek onmisbaar zijn wordt er binnen ons laboratorium ook veel onderzoek naar deze merkers gedaan.

Het tweede voorbeeld, beste mensen, waar ik met $u$ iets uitgebreider bij wil stilstaan betreft de farmacogenetica. Ik ben in 1997 in Maastricht komen werken en één van mijn opdrachten was toentertijd het opzetten van de moleculaire diagnostiek. Ik zelf heb farmacie gestudeerd en in de farmacogenetica komen farmacie en klinische chemie tezamen. Er zijn diverse definities van farmacogenetica maar er zijn er twee die de lading goed dekken.

'Farmacogenetica' is de naam van een wetenschappelijk specialisme dat zich richt op het leggen van verbanden tussen enerzijds genetische variatie en anderzijds verschillen in de werking van geneesmiddelen; iets eenvoudiger gezegd het is de zoektocht naar de mate waarin de genetische samenstelling van een individu invloed heeft op de respons op medicijnen.

Er zijn drie belangrijke redenen waarom de belangstelling voor de farmacogenetica toeneemt. In Amerika is bekend dat ca. $7 \%$ van alle ziekenhuisopnames medicijn-gerelateerd is, dit zal in ons land niet veel anders zijn. Daarnaast kan het gebruik van medicijnen veel rationeler plaats vinden en ten derde door betere moleculaire analyse technieken kunnen genetische afwijkingen die de afbraak of omzetting van medicijnen beïnvloeden sneller en relatief goedkoop gedetecteerd worden.

Als een patiënt medicijnen krijgt toegediend zijn de effecten die bereikt worden afhankelijk van diverse factoren. Vele zaken zijn breed bekend neemt de patiënt zijn of haar medicijnen op tijd of überhaupt wel in, heeft een patiënt geen andere aandoeningen en dan met name aan lever of nieren. Slikt hij nog andere medicijnen, want middelen kunnen ook elkaar beïnvloeden. Leeftijd kan een rol spelen zo kunt u zich vast en zeker voorstellen dat medicijnen bij kinderen of een zwangere een ander effect 
kan veroorzaken in vergelijking met een volwassen man. Daarnaast kunnen een dieet, roken en alcohol invloed op de werking van geneesmiddelen hebben. Maar veel minder bekend zijn de genetische factoren. In 2000 is er een rapport "Farmacogenetica - signalement" van de Gezondheidsraad verschenen waarin de farmacogenetica uitgebreid werd beschreven.

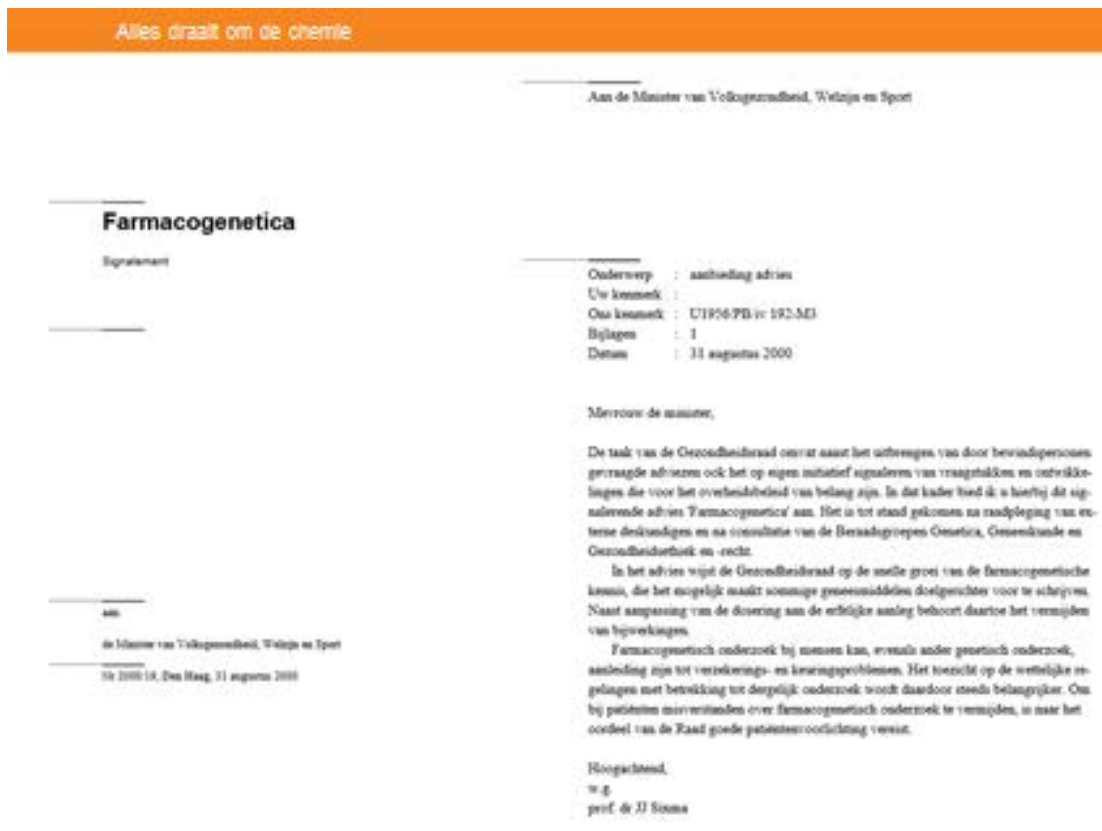

Uit dit rapport geschreven voor de minister van toentertijd en dat was mag ik gerust stellen was één van onze beste ministers van Gezondheidszorg wijlen Els Borst, wil ik enkele quotes naar voren halen: "In het advies wijst de Gezondheidsraad op de snelle groei van de farmacogenetische kennis, die het mogelijk maakt sommige geneesmiddelen doelgerichter voor te schrijven. Naast aanpassing van de dosering aan de erfelijke aanleg behoort daartoe het vermijden van bijwerkingen. Een reden voor de groeiende aandacht voor de farmacogenetica is het streven naar meer doelmatigheid in de gezondheidszorg. Kostenbesparingen zijn daardoor mogelijk, in het bijzonder indien ziekenhuisopnamen worden voorkomen."

Toen dit rapport in 2000 uit kwam en wij binnen ons laboratorium gestart waren met het opzetten van moleculair diagnostische technieken was dit een extra motivatie om ons op de farmacogenetica te storten. Alvorens verder op dit onderwerp in te gaan, gaan we ons eerst wat nader focussen op de achtergronden. Nog twee opmerkingen terzijde. Dit rapport uit 2000 is nog steeds opportuun en kan bijna ongewijzigd aan de huidige minister, Edith Schippers, worden aangeboden 


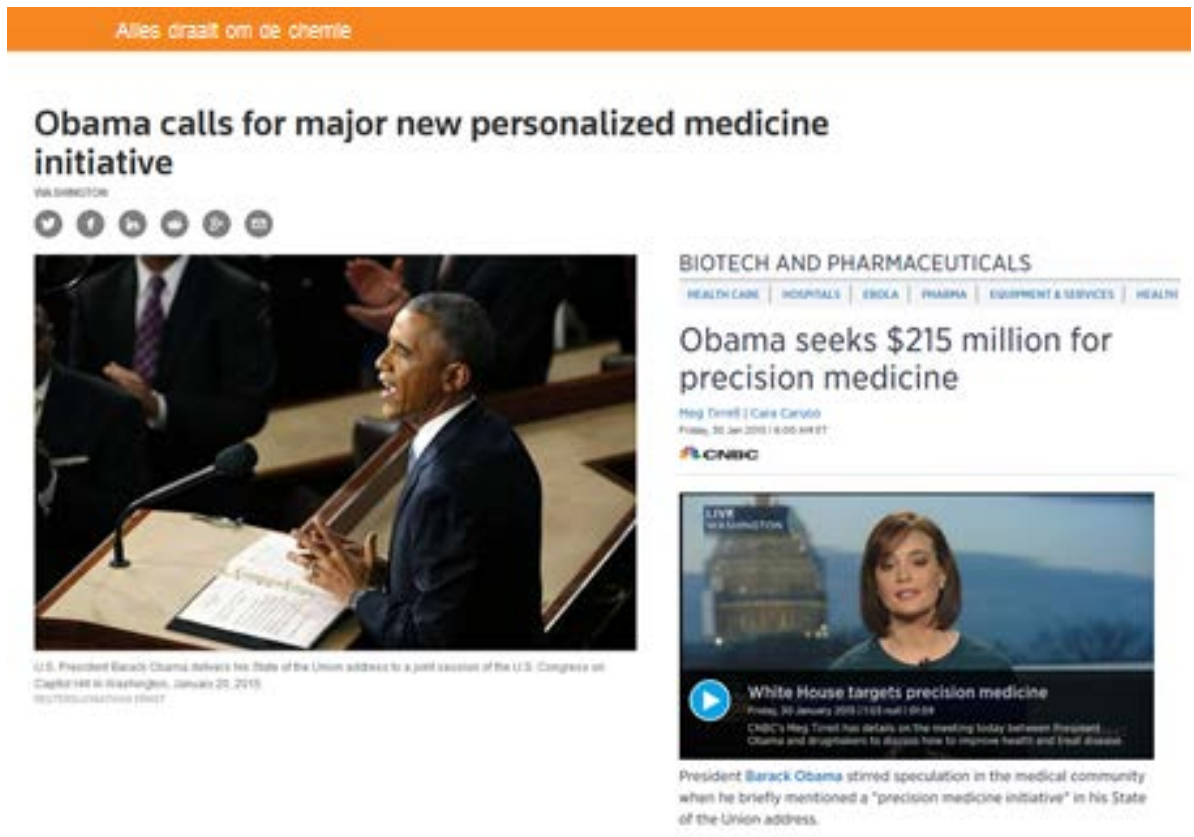

Maastricht UMC.

Ten tweede heeft president Obama in zijn State of the Union van afgelopen januari gepleit meer geld beschikbaar te stellen voor initiatieven op het gebied van "personalized medicine".

Als een patiënt een medicijn krijgt toegediend is dit voor het lichaam een vreemde stof en zal het lichaam proberen deze stof zo snel mogelijk weer uit te scheiden.

\section{Ales draat om de chemle}

\section{Na toediening medicijnen}

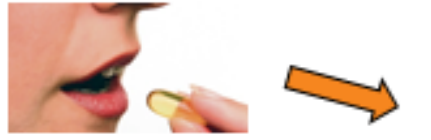

Inname medicijn

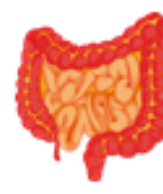

Opname in darm
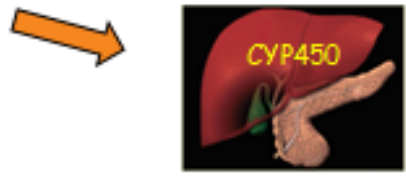

Metabolisatie in lever

door CYP450

Uitscheiding

metaboliet

in de urine
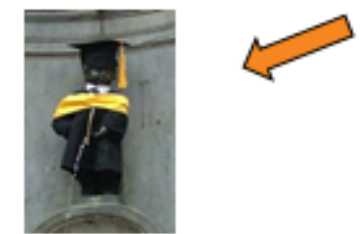
Over het algemeen zal dit gebeuren via de urine. Echter kan een medicijn ons lichaam niet zo maar verlaten maar zal nadat het in de darmen is opgenomen in het bloed eerst moeten worden omgezet in een makkelijk uit te scheiden stof. Die omzetting vindt over het algemeen plaats door enzymen in onze lever en wordt metabolisatie genoemd. De omgezette stof heet de metaboliet. Deze omzettingen of metabolisatie in de lever gaat onder andere via het Cytochroom P450 systeem. Wat kan er gebeuren?; patiënten die qua uiterlijk nauwelijks van elkaar verschillen krijgen dezelfde medicijnen toegediend doch bij de ene patiënt helpt het geneesmiddel en heeft het geen bijwerkingen en een andere patiënt krijgt wel bijwerkingen. Dit kan dus veroorzaakt worden door een genetisch verschil in het cytochroom P450 systeem. Dit noemen wij in de wetenschap een polymorfisme.

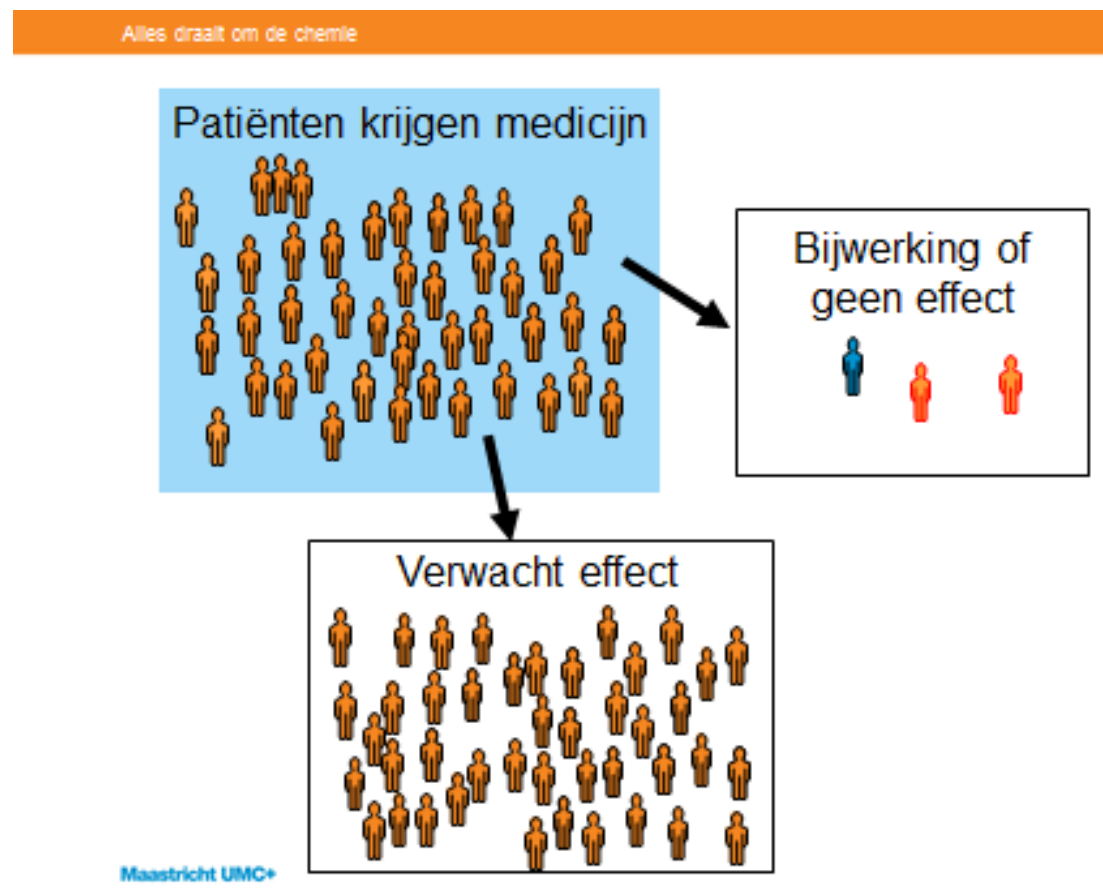

Op dit plaatje is dit weer gegeven en gelukkig is het over het algemeen zo dat de minderheid van de mensen die een geneesmiddel krijgt geen effect of een bijwerking vertoont.

Ik wil nu weer even met $\mathrm{u}$ terug naar het acute hartinfarct. Als er op tijd wordt ingegrepen en de patiënt overleefd het infarct dan krijgt hij na een eventuele operatie en herstel vervolgens diverse medicijnen voorgeschreven. Eén daarvan is een bètablokker bijvoorbeeld metoprolol. Dit wordt gemetaboliseerd door Cytochroom P450. En bij te hoge doseringen zijn er diverse bijwerkingen van bekend. 


\title{
Hartinfarct en farmacogenetica
}

\author{
Klinisch voorbeeld van CYP2D6
}

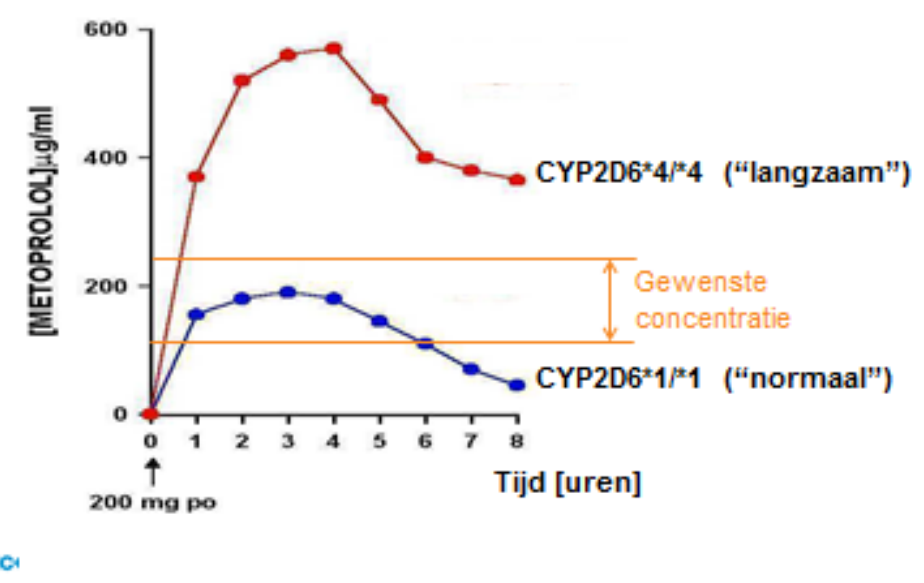

$U$ ziet hier wat het verschil in concentratie in het bloed van 2 patiënten waarvan er één een normale metaboliseerder is en de andere een polymorfisme heeft en daardoor een langzame metaboliseerder. Op de horizontale as staat de tijd na inname van de tablet metoprolol en op de verticale as de hoeveelheid metoprolol in het bloed van de patiënt.

De gewenste concentratie bevindt zich tussen de oranje lijnen. De langzamere metaboliseerder weergegeven door de rode lijn heeft dus een te hoge concentratie van metoprolol in zijn bloed in vergelijking met de normaal metaboliseerder weergegeven door de blauwe lijn en daardoor meer kans op bijwerkingen. De langzame metaboliseerder zou dus baat hebben bij een lagere dosering van metoprolol.

Ik heb hier als voorbeeld het CYP2D6 genomen, dit is een bepaald gedeelte van het Cytochroom P450 systeem. Zo zijn er grofweg gezegd zo'n 5 belangrijk verschillende CYP systemen. CYP2D6 is daarvan één van de belangrijkste. Door de Cytochroom P450 polymorfismen of te wel het genetisch CYP profiel op voorhand te bepalen is het mogelijk te voorspellen hoe een bepaald geneesmiddel gemetaboliseerd gaat worden. Zo kennen we langzame, matige, normale en snelle metaboliseerders. Het is bekend dat 7 tot $10 \%$ van de Nederlandse bevolking een langzame metaboliseerder is voor het CYP2D6. Dus als $u$ om zich heen kijkt dan bevindt zich op de rij waarin u zit zich statistisch gezien één langzame metaboliseerder voor CYP2D6.

Stel dat u die langzame metaboliseerder zou zijn en u krijgt een geneesmiddel voorgeschreven zou u dus een lagere dosering van het middel moeten krijgen of mogelijk het middel zelfs helemaal niet moeten 
voorgeschreven krijgen. Momenteel is het zo dat indien een patiënt veel bijwerkingen door geneesmiddelen vertoont er binnen het MUMC plus een grote kans bestaat dat er farmacogenetisch onderzoek wordt aangevraagd. Binnen ons laboratorium voeren wij dit onderzoek zo'n 500 maal per jaar uit. Wij doen dat niet alleen voor ons ziekenhuis maar voor de gehele regio Limburg. Toen ik indertijd met dit onderzoek startte was mijn insteek dat iedereen binnen afzienbare tijd een genetisch geneesmiddelen paspoort zou hebben. Hierin zou dan kunnen staan welke polymorfismen een persoon heeft en welke medicijnen hij of zij absoluut niet voorgeschreven zou moeten krijgen. Dat hier veel haken en ogen aan zitten is mij gedurende de afgelopen 18 jaar wel duidelijk geworden, echter blijf ik geloven in een prachtige toekomst voor de farmacogenetica, vooral ook omdat dit voor de patiënt van groot belang is. Daarom zullen wij hier in Maastricht veel onderzoek en pionierswerk in blijven verrichten. De stap naar de zogenaamde "personalized medicine" kan niet ver weg meer zijn.

Het derde voorbeeld dat ik u wil noemen is diabetes mellitus wat letterlijk betekent "mierzoete doorstroming" en in de volksmond bekend staat als suikerziekte of suiker. De naam is ontstaan doordat vroeger, alvorens er chemische analyses bestonden, u weet wel... waar het allemaal om draait, de arts zijn diagnose stelde door de urine van een patiënt te proeven. Als dit zoetig smaakte werd de diagnose gesteld.

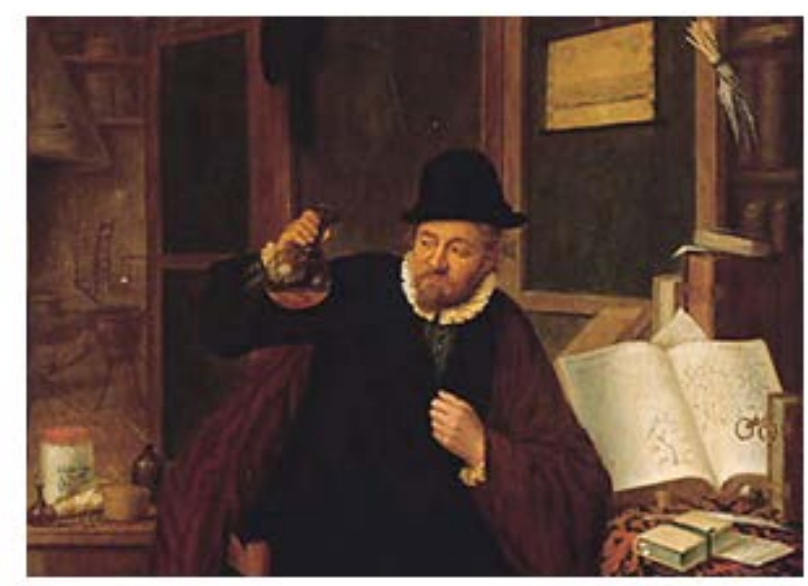

Het verhaal gaat dat de wat kieskeurigere geneesheren; zoals u er hier één ziet geschilderd door Adriaen van Ostade, de urine buiten zetten en keken of er wespen of andere insecten op af kwamen 
Er zijn veel symptomen die kunnen wijzen op diabetes. Zo kan veel plassen en veel drinken of onverklaarbaar gewichtsverlies duiden op diabetes. Heden ten dage zijn er ruim een miljoen mensen in Nederland die diabetes hebben en de schatting is dat zo'n 250.000 hiervan zelf geen weet hebben. Het is momenteel zo dat er in Nederland per week circa 1000 diabetes patiënten bij komen. Dit zijn natuurlijk gigantische aantallen. Om de diagnose diabetes te stellen speelt het laboratorium een belangrijke rol.

In deze tabel ziet u de vier criteria waarop de diagnose van diabetes gesteld kan worden.

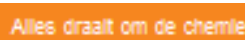

\begin{tabular}{|c|c|c|}
\hline & Diagnose Diabetes mellitus & Opmerking \\
\hline 1 & $\mathrm{HbA} 1 \mathrm{c}>47 \mathrm{mmol} / \mathrm{mol}$ of $6,5 \%$ of & $\begin{array}{l}\text { gestandaardiseerde } \\
\text { methode }\end{array}$ \\
\hline 2 & Nuchtere glucose $>7 \mathrm{mmol} / \mathrm{L}$ & $\begin{array}{l}\text { langer dan } 8 \text { uur niets } \\
\text { gegeten }\end{array}$ \\
\hline 3 & $\begin{array}{r}\text { Glucose }>11,1 \mathrm{mmol} / \mathrm{l} \text { na2-uur OGTT } \\
\text { of }\end{array}$ & $\begin{array}{l}\text { belasting met } 75 \mathrm{~g} \\
\text { glucose }\end{array}$ \\
\hline 4 & Random meting $>11,1 \mathrm{mmol} / \mathrm{l}$ & $\begin{array}{l}\text { bij symptomen hoge } \\
\text { bloedsuikerspiegel }\end{array}$ \\
\hline & Bij afwezigheid symptomen test herhalen & \\
\hline
\end{tabular}

De eerste is indien de $\mathrm{HbA1c}$, in een afgenomen bloedmonster bij een persoon groter is dan $6,5 \%$ wat overeenkomt met $47 \mathrm{mmol} / \mathrm{mol}$. De HbA1c geeft de gemiddelde bloedglucosespiegel over de afgelopen 2 tot 3 maanden weer. De tweede is de bepaling in een nuchter bloedmonster, indien iemand na minimaal 8 uur vasten een glucose concentratie hoger dan $7 \mathrm{mmol}$ per liter heeft. Het derde criterium is indien een persoon belast wordt met een standaard glucose oplossing van 75 gram per liter, wat globaal overeenkomt met een normaal ontbijt dient zijn glucosespiegel na 2 uur in ieder geval onder de 11,1 mmo/ per liter te liggen. En de laatste is indien er at random een bloedmonster wordt genomen en deze is hoger dan $11,1 \mathrm{mmol}$ per liter is heeft deze persoon diabetes mellitus. De eis dat deze bepalingen verricht dienen te worden binnen een geaccrediteerd klinisch chemisch laboratorium moge u hopelijk duidelijk zijn. 
Het laatste voorbeeld dat ik u wil schetsen betreft de zogenaamde pointof-care testen vaak afgekort tot POCT. Dit behelst het uitvoeren van analytische laboratoriumtests in de directe nabijheid van de patiënt. Deze tests worden over het algemeen niet uitgevoerd door analisten maar door niet analytisch geschoolde mensen zoals verpleegkundigen, doktersassistenten maar ook patiënten zelf kunnen deze tests uitvoeren. Omtrent deze laatste vorm is recent veel ophef geweest. Hier ziet u een artikel uit een groot landelijk ochtendblad.

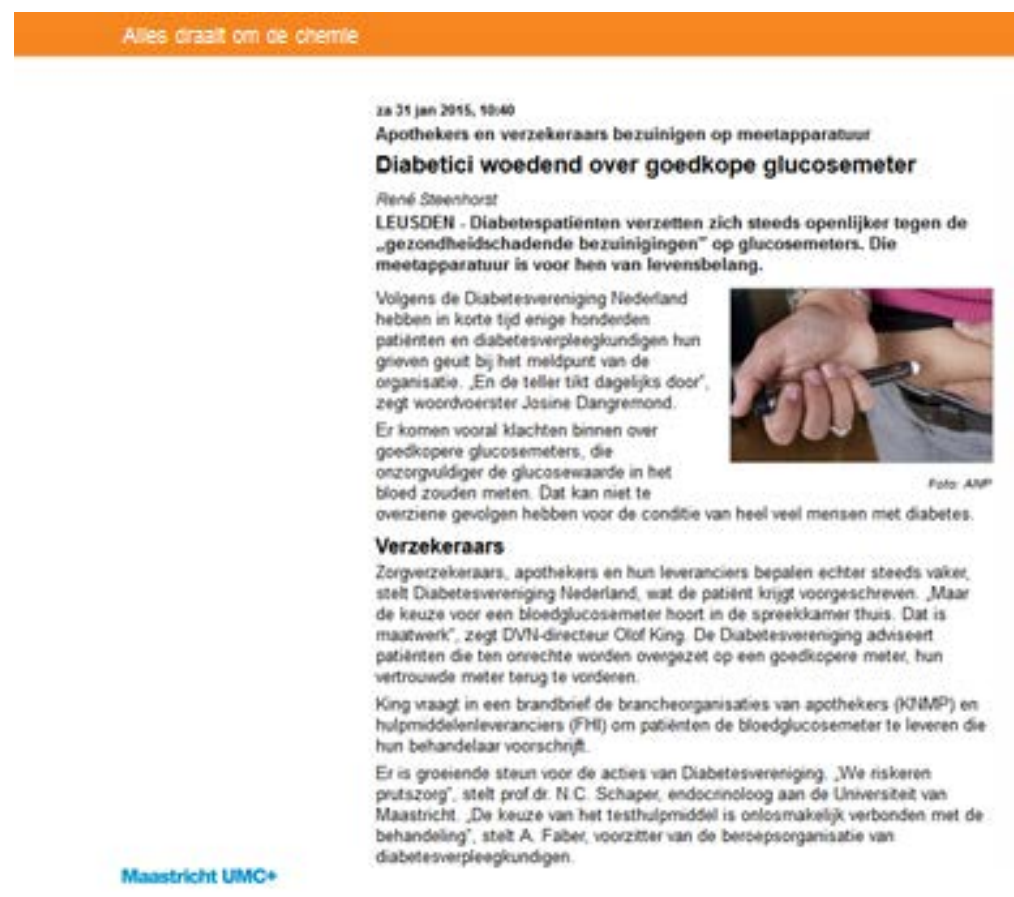

Ik kom dan weer terug bij de Diabetes patiënten, als de diagnose is gesteld en zij behandeld worden met insuline controleren zij zelf met eigen glucosemetertjes hun bloedspiegel. Waarschijnlijk kent u vast wel iemand uit uw eigen familie of kennissenkring die hier gebruik van maakt. Aan de hand van de gemeten waarde kunnen zij zelf hun glucosespiegel instellen. Door bezuinigingen in de zorg komen er steeds goedkopere metertjes op de markt. Het gevaar is dat deze metertjes niet de gewenste kwaliteit leveren en zoals professor Schaper vanuit ons UMC in het artikel zegt we riskeren dan "prutzorg". Er is in deze een belangrijke rol weggelegd voor klinisch chemisch Nederland. Wij weten aan welke standaarden de glucosemetertjes moeten voldoen en kunnen dat ook in het laboratorium met betrouwbare analyse apparatuur uittesten. Maar deze problematiek geldt niet alleen voor de glucosemetertjes. 
Maar naast de glucosemeters die door de patiënten wordt gebruikt vinden er ook binnen het ziekenhuis en de huisartsenpraktijken ontwikkelingen plaats. Er komen steeds meer zogenaamde nietinstrumentele analyses op de markt. $U$ ziet hier een aantal voorbeelden.

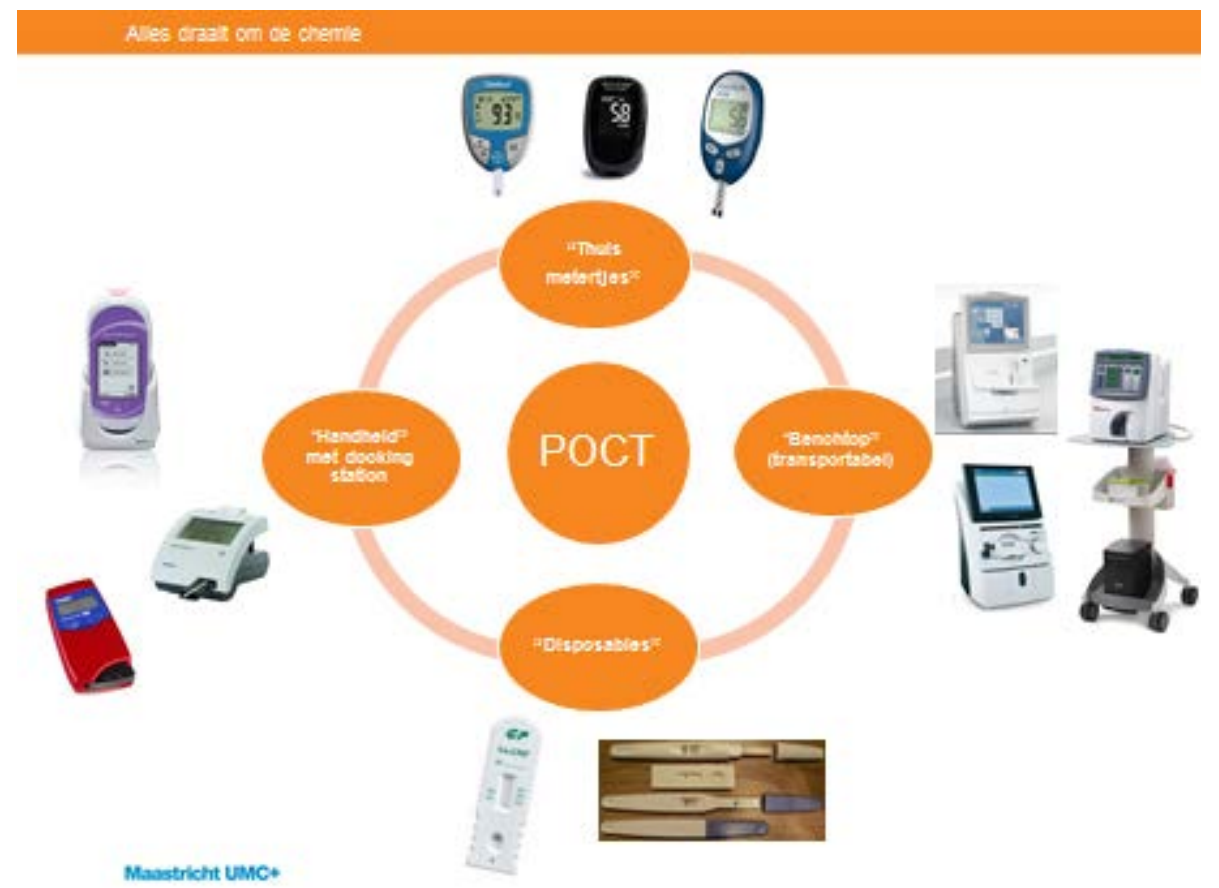

Het is algemeen geaccepteerd dat laboratoriumspecialisten klinisch chemie in ziekenhuizen verantwoordelijk zijn voor de POCT metingen. Zo beslist het laboratorium welke apparatuur geschikt is, verzorgen de implementatie, certificeren de gebruikers, doen het onderhoud en kwaliteitscontroles, lossen storingen op, maken voorschriften en zorgen ervoor dat de resultaten op de juiste wijze in het ziekenhuisinformatiesysteem beschikbaar komt. Naast toepassingen binnen het ziekenhuis zal deze apparatuur in de toekomst ook veel meer gebruikt gaan worden in bijvoorbeeld huisartsen praktijken. Dus brengen wij niet alleen de chemie naar de specialisten in het ziekenhuis maar ook naar de huisartsen. Als voorbeeld wil ik hier noemen de CRP-test. De huisartsen in Nederland maken veelal gebruik van de Nederlandse Huisartsen Geneeskunde standaarden beter bekend als de NHGstandaarden. In de standaard "Acuut hoesten" heeft de CRP een belangrijke rol of de huisarts wel of geen antibiotica voorschrijft. Geadviseerd wordt om met behulp van een Point-of-care-meter tijdens het consult een CRP te meten. Vanzelfsprekend is de anamnese en klinisch onderzoek van groot belang er is echter wetenschappelijk onderzocht dat er frequent 'voor de zekerheid' antibiotica wordt voorgeschreven. Dat gebeurt in ruim de helft, te weten $53 \%$ van de 
gevallen. Indien een huisarts beschikt over de CRP-sneltest schrijven zij maar in 31\% dus zo'n derde van de gevallen antibiotica voor. Aangezien huisartsen in de wintermaanden dagelijks patiënten met luchtwegklachten in hun praktijk krijgen, kan het gebruik van de POCTCRP test leiden tot een zeer forse verlaging van antibioticagebruik. Het zal u hopelijk duidelijk zijn geworden dat wij de huisarts hier met raad en daad kunnen bij staan.

Geachte toehoorders, tot zo ver de voorbeelden uit de klinische praktijk. Ik had natuurlijk nog veel meer voorbeelden zoals cholesterol, de bloedstolling, reuma factoren of de schildklier kunnen kiezen. Maar vrij vertaald naar Louis Pasteur die zei "er zit meer chemie in een fles wijn dan in alle boeken", wil ik nu doorgaan naar de laatste 2 onderwerpen want de wijn wacht op ons.

Binnen het MUMC+ is de klinische chemie de laatste jaren erg veranderd. De grootste verandering is het samen gaan van drie laboratoria te weten de hematologie, medische immunologie en klinische chemie tot het CDL. Hieraan ten grondslag lagen diverse oorzaken. Zo wilde we de kwaliteit verbeteren, snellere en efficiëntere diagnostiek leveren en meer service bieden. Dit alles heeft geresulteerd in een hypermodern techniek georiënteerd laboratorium wat met behulp van lean principes is opgezet.

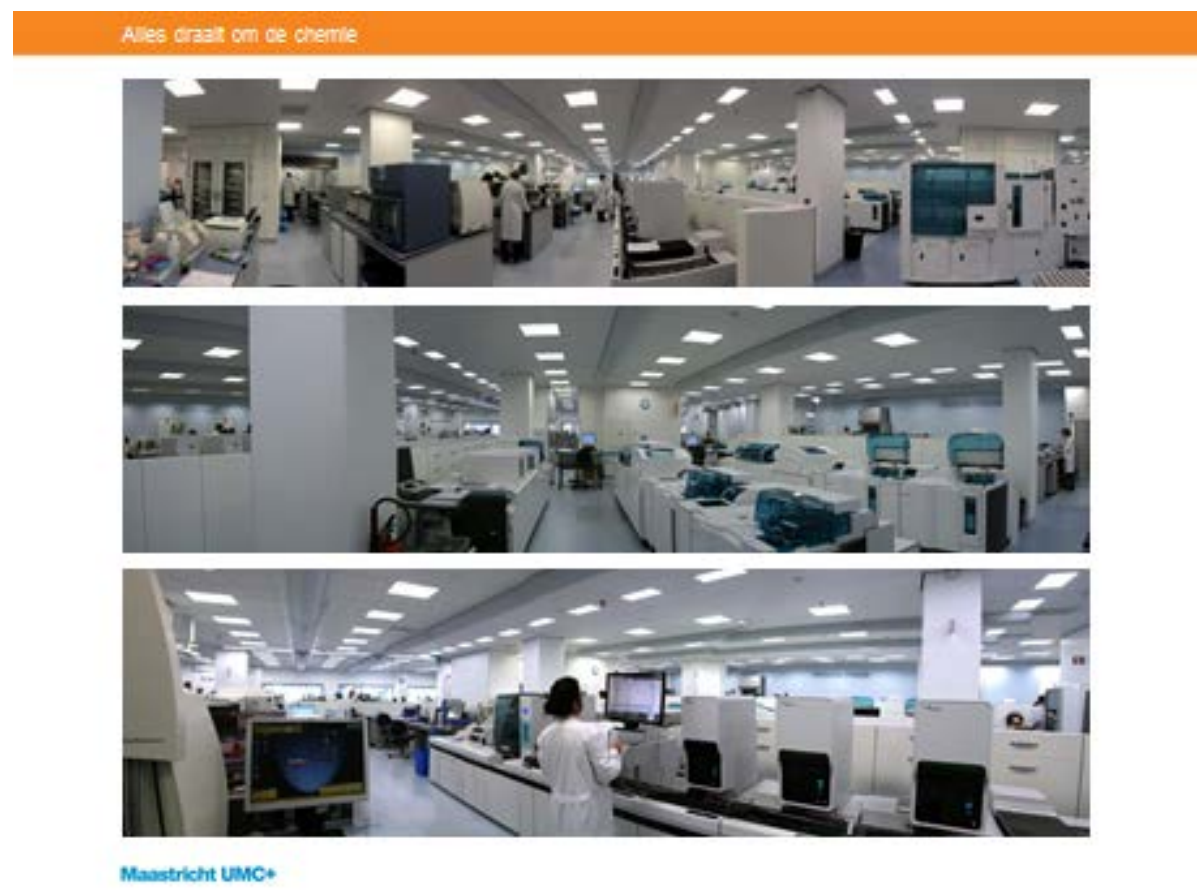


Momenteel zijn wij het enige academisch ziekenhuis waar de gehele klinische chemie, hematologie, immunologie en infectie-serologie binnen één laboratorium plaats vindt. In de laboratorium wereld wordt dit ontschotting genoemd. En wij zijn nog niet klaar met de ontschotting want wij zijn momenteel bezig om ook tests vanuit het laboratorium van de klinische farmacie oftewel de apotheek binnen het CDL te gaan laten plaats vinden. Het goede van de ontschotting is dat het gehele analytische proces veel efficiënter plaats vindt waardoor er minder apparatuur nodig is, vanzelfsprekend blijft iedere laboratorium specialist verantwoordelijk voor zijn eigen vakgebied. Wij denken met dit laboratorium klaar te zijn voor de toekomst want ook binnen de laboratoriumwereld heeft de marktwerking zijn intreden gedaan en wij hebben hier met ons laboratorium reeds op ingespeeld.

Binnen het CDL zijn er 3 dus afdelingen samen gevoegd, we zijn momenteel met zo'n 230 mensen en er liggen nog veel uitdagingen te wachten. Alle drie de laboratoria hadden hun eigen cultuur dit moet nu één CDL cultuur gaan worden. Met behulp van operational excellence en coachend leiderschap zullen wij dit via diverse projecten gaan oppakken.

Binnen het CDL verrichten wij naast de patiëntenzorg ook onderzoek en onderwijs. Wat dit laatste betreft geven wij onderwijs aan geneeskunde studenten tijdens hun coschappen en participeren in enkele blokken van de bachelor fase. Daarnaast verzorgen wij cursussen voor studenten Biomedische technologie. En geven bij- en nascholingen voor huisartsen. Wij hebben afgelopen december weer de visitatie voor de opleiding klinische chemie en laboratoriumgeneeskunde gehad en de bevoegdheid is ons door onze beroepsgroep wederom voor vijf jaar toegekend.

Wij hebben altijd twee tot drie assistenten in opleiding. Geneeskunde, HLO en MLO studenten lopen diverse stages binnen het CDL. Onderzoek verrichten we op diverse fronten, genoemd zijn al de hartmerkers en de farmacogenetica maar ook op endocrinologisch, immunologisch en op stollingsgebied zijn de laboratoriumspecialisten binnen het CDL zeer actief. Wij zullen dit voortzetten en waar mogelijk uitbreiden. Hiervoor is samenwerking met de diverse vakgroepen en onderzoeksscholen van het MUMC plus onontbeerlijk en wij zullen immer streven naar de juiste chemie.

In Maastricht is naast het Universitair Medisch Centrum geen perifeer ziekenhuis in de nabijheid. Daarom verzorgen wij in tegenstelling tot de overige academische centra ook de diagnostiek voor de huisartsen. Dit doen wij voor het adherentie gebied Maastricht en Heuvelland. Door de vercommercialisering in de medische wereld komen er ook andere 
aanbieders voor de laboratoriumzorg in onze regio en moeten wij dus de strijd met deze laboratoria aangaan. Ik ben er van overtuigd dat het voor de patiënt van groot belang is dat de laboratoriumdiagnostiek die wordt aangeboden van kwalitatief hoogstaand niveau is en dient te passen in de ketenzorg. Binnen het CDL staan wij 24 uur per dag paraat om voor onze aanvragers zowel binnen het MUMC plus als er buiten, zoals de huisartsen, verpleegklinieken en GGZ instellingen, diagnostiek te verrichten. Er zijn commerciële aanbieders die alleen routine diagnostiek aanbieden van 9 tot vijf. Deze concurrentiestrijd is vanzelfsprekend lastig en het laatste woord is hierover nog niet gezegd. Ook de zorgverzekeraars mengen zich in deze strijd en mijn angst is dat geld hierin een steeds belangrijkere rol gaat spelen. De klinische chemie is in Nederland goed georganiseerd en staat kwalitatief op een hoog niveau. Het is de taak van onze beroepsgroep dit zo te houden echter dient de politiek ervoor te zorgen dat niet de financiële kaders de overhand gaan krijgen. Mijns inziens is de combinatie van marktwerking en gezondheidszorg letterlijk "killing".

En ik constateer ook dat de chemie tussen de spelers in het zorgveld onder spanning komt te staan, dit zal ten koste gaan van de patiënt.

Eigenlijk ben ik zo al toe gekomen aan enkele toekomst bespiegelingen binnen ons vakgebied. Wat we tevens kunnen constateren is dat er in Nederland verhoudingsgewijs niet veel geld aan laboratoriumdiagnostiek wordt uitgegeven

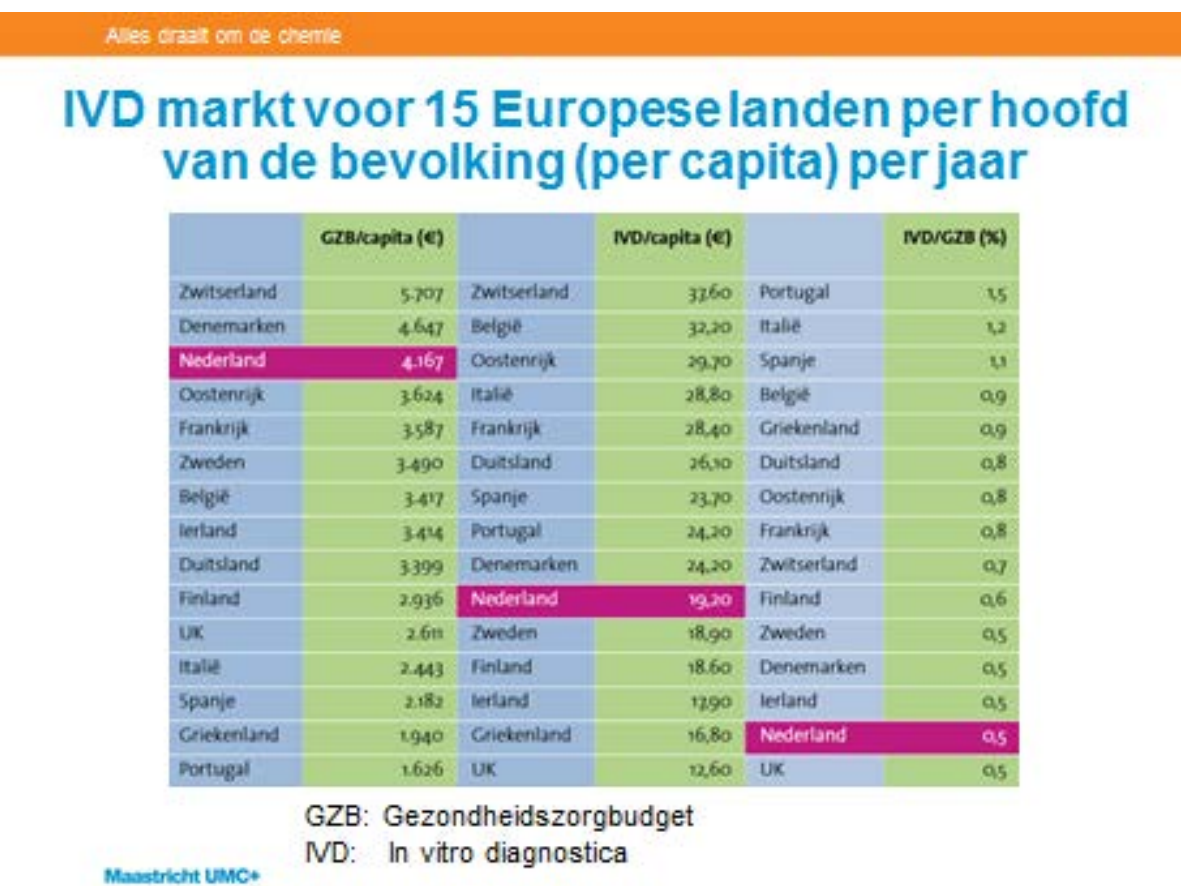


Als we ervan uitgaan dat de laboratoriumdiagnostiek grotendeels plaatsvindt met behulp van IVD's dat staat voor in-vitro diagnostica kunt $u$ in de bijgaande tabel in de laatste kolom zien dat wij in Nederland slechts $0,5 \%$ van het totale gezondheidszorgbudget GZB uitgeven aan in-vitro diagnostica. Dus in totaal geven wij in Nederland aan in-vitro diagnostica 19 euro 20 per persoon uit dit staat in de middelste kolom weergegeven en in de eerste kolom ziet $u$ dat het gehele gezondheidszorgbudget in ons land 4167 euro per hoofd van de bevolking bedraagt. Als we dit bijvoorbeeld vergelijken met België, waar veel commerciële laboratoria actief zijn. Dan ziet u dat aldaar er 32 euro 20 per persoon per jaar aan IVD's wordt uitgegeven, terwijl het totale gezondheidszorgbudget 3417 euro per persoon is. Deze gegevens zijn afkomstig van een onafhankelijke non-profit organisatie, de EDMA de European Diagnostic Manufacturers Association, gevestigd in Brussel.

Ik denk dat de ontschotting die binnen ons ziekenhuis in gang is gezet zich in zal gaan uitbreiden over de muren van de ziekenhuizen heen en de technologische ontwikkelingen zullen ons hierbij kunnen helpen. Wij zullen in Nederland met de laboratoria meer moeten gaan samenwerken en specialistisch en duur onderzoek zal meer geclusterd uitgevoerd gaan worden. Door samenwerking zal er een besparing gerealiseerd kunnen worden, echter van het huidige bedrag wat wij in Nederland uitgeven aan laboratoriumzorg kan zoals in Europees verband onderzocht niet veel meer af. En ik kan mij geen ziekenhuis zonder laboratorium voorstellen. Een laboratorium in de wei, zoals zelfstandige laboratoria los van een ziekenhuis weleens worden genoemd is geen gewenste situatie.

De laboratoriumspecialist zal in het ziekenhuis aanwezig moeten blijven om aldaar zijn expertise ter beschikking van de aanvragers en patiënten te stellen. Zo kan hij of zij ervoor zorgen dat er adequate laboratoriumdiagnostiek blijft plaatsvinden.

Aan het einde van mijn rede kom ik toe aan mijn dankwoord. Ik wil op voorhand iedereen bedanken die heeft bijgedragen aan de tot stand koming van mijn benoeming. Een aantal wil ik er uitlichten maar daarbij kan ik vanwege de tijd niet iedereen noemen. Dus mocht ik u niet vermelden dan bied ik $u$ hierbij mijn verontschuldiging aan maar heb $\mathrm{u}$ bij deze wel bedankt.

Binnen het Maastricht Universitair Medisch Centrum plus gaat mijn dank uit naar de Raad van Bestuur, Guy Peeters, Albert Scherpbier, Lou Brans Brabant, Marja van Dieijen-Visser, Frits van Merode en Nanne de Vries. Jullie betrokkenheid en manier van besturen is voor mij een bron van inspiratie. 
En ik dank hierbij tevens het college van Toezicht.

Na mijn studie Farmacie heb ik het geluk gehad in Utrecht mijn promotieonderzoek te mogen uitvoeren. Bij Willy Underberg, Auke Bult en Jos Beijnen heb ik ontzettend veel geleerd en niet alleen op wetenschappelijk vlak. Ik ben jullie daar nog steeds dankbaar voor.

Na mijn promotieonderzoek had ik een baan binnen een laboratorium van een farmaceutisch bedrijf. Echter alvorens ik daar mee kon beginnen werd ik in het Leyenburg ziekenhuis aangenomen als klinisch chemicus in opleiding, waardoor mijn droom werkelijkheid werd. Ik was de eerste assistent in het Leyenburg en Arnold Lombarts, Wim de Kieviet en Paul Franck hebben mij het vak van klinisch chemicus op prima wijze bijgebracht. Arnold, Wim en Paul dank daarvoor en ik vind het op zijn Haags gezegd "onwijs geinig" dat jullie hier aanwezig zijn.

Na deze opleiding werd ik in Maastricht aangenomen door Marja van Dieijen-Visser. Een Hagenees in Limburg is misschien een vreemde combinatie, maar het is één van de belangrijkste gebeurtenissen in mijn carrière geweest. Beste Marja, ik heb ontzettend veel van je geleerd en onze samenwerking was en is immer zeer prettig. Jouw manier van leidinggeven en mensen stimuleren is voor mij een groot voorbeeld geweest. Met je overgang naar de Raad van Bestuur en als toekomstig voorzitter heb je een prachtige stap gemaakt en ik ben blij dat ik de door jou achtergelaten mooie afdeling verder gestalte mag gaan geven. Mijn dank is groot.

De samenwerking met mijn naaste collegae laboratoriumspecialisten, het MT van de RVE, alle analisten, medewerkers, assistenten en onderzoekers van het CDL is reuze prettig en constructief. Ik dank jullie hiervoor hartelijk en hoop dat we dit in de toekomst blijven voortzetten zodat we in een prima sfeer binnen een goed functionerende afdeling en eenheid werkzaam blijven. ledere dag ga ik met plezier naar het lab en ben trots op wat we met z'n allen bereikt hebben.

Mijn beste vrienden, wij hebben aan weinig woorden genoeg en als we bij elkaar zijn is het wat we ook doen dikke pret, maar zijn jullie eigenlijk wel aanwezig?

Zelf heb ik een kleine fijne familie maar heb er gratis al zo'n 32 jaar een prachtige schoonfamilie bij gekregen. Op de Jan van Banningstraat heb ik mij van het begin af aan thuis gevoeld. Joop en family ik wil jullie daar hartelijk voor bedanken en ik weet zeker dat als Qrien en Paul hierbij waren geweest zij er erg van had genoten.

Ton stimuleerde mij om als maar door te leren. 
En moeder Jenny, wat jij met mij allemaal hebt moeten meemaken kan ik hier niet uiteenzetten, maar als u daarin geïnteresseerd ben wil zij u er waarschijnlijk straks tijdens de borrel vast iets over vertellen. Je zag van al mijn kattenkwaad en vreemde capriolen altijd de humor in. Jij heb me de chemie van jongs af aan bijgebracht, dat begon met het LNA en een chemiedoos, en je hebt me altijd volledig gesteund en ondersteunt. Zelfs nu nog, want toen ik je vertelde dat ik hoogleraar werd was het eerste wat je zei: je krijgt van mij je toga. Een betere opvoeding had ik me niet kunnen wensen.

Tico en Ceres, ik hoor mensen weleens mopperen op hun puberende kinderen. Ik krab me dan achter de oren en vraag me af of jullie überhaupt wel gepuberd hebben. Jullie hebben er voor gezorgd dat ik tussen 1990 en 2011 een geweldige tijd heb gehad. Tegenwoordig komen jullie nog sommige weekenden en met speciale gelegenheden thuis, vaak tezamen met Lotte of Rudo en het is dan altijd gezellig. Ik kan het niet laten jullie als opvoeder toch nog wat advies mee te geven, studeer en werk hard en onthoud, een vrolijk gezicht brengt overal licht.

Tot slot, lieve Margot. Ik zal nooit vergeten dat we elkaar voor het eerst zagen in de Eloutstraat jij te voet en ik op de fiets; nadat we elkaar waren gepasseerd draaide we allebei onze hoofden om. We zijn elkaar daarna nooit meer uit het oog verloren. Meer hoef ik eigenlijk niet te zeggen, - maar toch nog even snel twee zinnetjes. Zonder jou was wat we nu hebben bereikt nooit gelukt. Mijn dank en liefde zijn enorm en ook jij weet waar alles omdraait: onze chemie.

Ik heb gezegd.

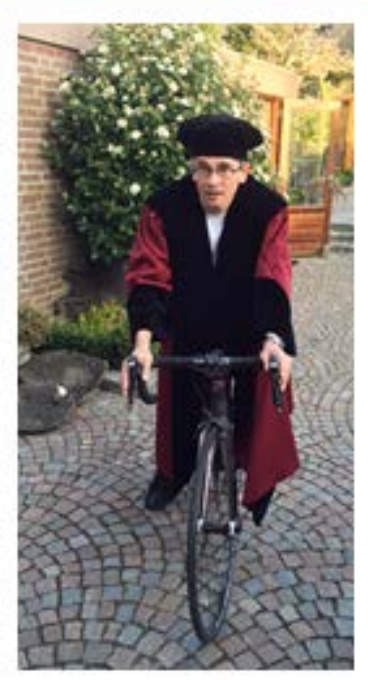

Ik heb gezegd! 